\title{
New records of Orthoptera in the Bieszczady Mountains (Southeast Poland) with special regard to the genus Isophya
}

\author{
Jörn THEUERKAUF*, Sophie ROUYS*, Günter GREIN** and Andreas BECKER*** \\ *Carpathian Wildlife Research Station, Museum and Institute of Zoology, Polish Academy of Sciences, Betzka 24, \\ 38-700 Ustrzyki Dolne, Poland; correspondence address: Jörn Theuerkauf, BP 2549, 98846 Nouméa Cedex, New \\ Caledonia, fax: +687-254473; e-mail: jtheuer@miiz.waw.pl \\ **Ulmenweg 31, D-31139 Hildesheim, Germany \\ ***Die Alme 22a, D-64385 Reichelsheim, Germany
}

\begin{abstract}
Human use of slope and subalpine meadows in the Bieszczady Mountains (Southeast Poland) has greatly decreased in the last 60 years. We investigated whether the change in land use has affected the species composition of the Orthopteran fauna. From 1996-2002, we found 35 species of Orthoptera. We recorded four Isophya species, of which I. kraussii and I. pienenis were not previously reported for the Bieszczady. Other new species for the Bieszczady were Chorthippus pullus and Omocestus rufipes. We assume that three Orthoptera species have disappeared from the Bieszczady due to decreased grazing but that the Carpathian species have been little affected.
\end{abstract}

Key words: Bieszczady National Park, Isophya, land use, Orthoptera, Poland

\section{INTRODUCTION}

In the $19^{\text {th }}$ and first half of the $20^{\text {th }}$ century, the Bieszczady Mountains (about $2000 \mathrm{~km}^{2}$ ) were an agricultural region covered with about $40 \%$ of arable land and $40 \%$ forest (Augustyn 2004). Over this period, cattle grazed on subalpine meadows (1000-1350 m). From 1939 to 1951, most of the human population of the Bieszczady was deported for a range of political reasons (Augustyn 2004). Consequently, most agricultural land became fallow until the 1960s when large state farms reclaimed meadows lower than about $1000 \mathrm{~m}$ a.s.l. Simultaneously, most subalpine meadows became part of the Bieszczady National Park (Fig. 1). In the 1960s, Bazyluk (1971) recorded 43 Orthoptera species in the Bieszczady on slope meadows, many of which were still grazed by sheep, and subalpine meadows, which had not been used for about 20 years. When the state farms became dissolved in the 1980s, most slope meadows were no longer used. Today, less than $10 \%$ of the area consists of arable land, subalpine meadows have not been used for 60 years, most meadows at lower altitudes are only occasionally used, and about $70 \%$ of the area is forested. This major shift in land use is likely to have affected the Orthoptera fauna, but since Bazyluk's (1971) study there have been no other studies of Orthoptera in the area (Liana 2000), except for incidental records (Hochkirch 1996). The objectives of this article are to update the Orthoptera list of the Bieszczady, determine whether the distribution of some species has been affected by the changes in land use, and provide information that might be helpful for an overdue revision of the genus Isophya Brunner von Wattenwyl, 1878 (Heller et al. 2004).

\section{METHODS}

We searched for Orthoptera on the 30.06-13.07.1996, 14-19.07.1997, 2-8.08.1998, 2230.08.2000, and 26.05-11.08.2002 on 36 sites in the study area ranging between 340 and 1300 $\mathrm{m}$ a.s.l (Fig. 1). We identified most species in the field by their stridulation (except Barbitistes, 
Isophya, Miramella, and Tetrix spp.) or by their morphology. In 1996 and 1997, we searched for calls of Isophya males with a QMC mini bat detector at sites 26 and 29-31 in order to find and distinguish Isophya species (method described in Froehlich \& Holtzem 1987). We additionally collected specimen of Isophya species, of which the males were identified by K.G. Heller. Scientific names follow the check-list of European Orthoptera (Heller et al. 1998).

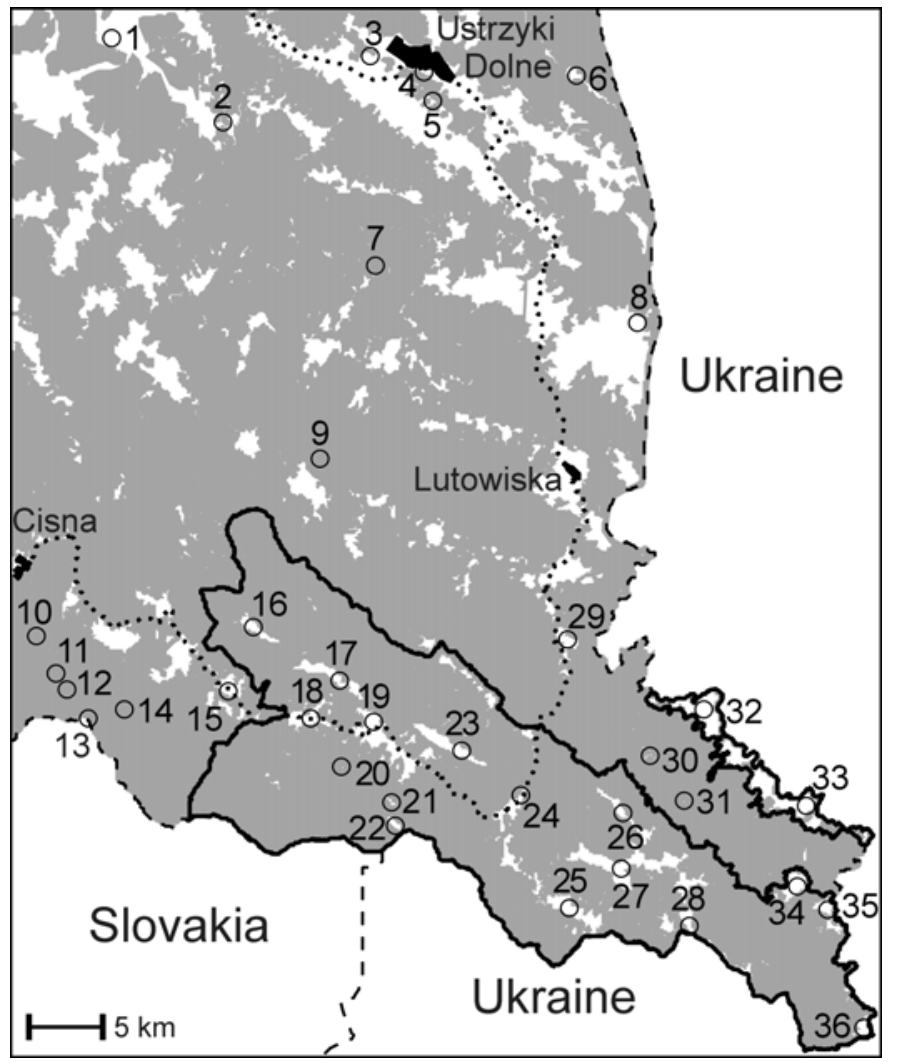

Fig. 1. Locations of 36 sites (open circles) searched for Orthoptera in the Bieszczady Mountains (Southeast Poland) in 1996-2002. Solid lines: the 2 parts of the Bieszczady National Park $\left(270 \mathrm{~km}^{2}\right)$, dotted lines: main roads, dashed lines: state borders, grey area: forest. Sites: 1: meadows near Zwierzyn (340 m), 2: wet meadow and sandpit near Solina (400 m), 3: slope meadows on Mały Król (620-650 m), 4: slope meadows in Ustryki Dolne (480-600 m), 5: slope meadows and clearings on Gromadzyn $(610-650 \mathrm{~m}), 6$ : meadows and gravel bank in Stebnik valley (400-520 m), 7: slope meadows in Paniszczew valley $(480-550 \mathrm{~m})$, 8: slope meadows near Bystre $(650 \mathrm{~m})$, 9: slope meadows near Krywe, 10: subalpine meadows on Worwosoka $(1000 \mathrm{~m}), 11$ : subalpine meadows on Szczawnik $(1050 \mathrm{~m})$, 12: subalpine meadows on Jasło (1100-1150 m), 13: subalpine meadows on Okraglik (1030 m), 14: subalpine meadows on Fereczata $(1050-1100 \mathrm{~m}), 15$ : slope meadows in Wetlina $(630 \mathrm{~m}), 16$ : slope meadows on Smerek $(680 \mathrm{~m}), 17$ : subalpine meadows on Połonina Wetlińska $(1050-1230 \mathrm{~m}), 18$ : slope meadows and wet meadows in the Wetlinka valley (700$850 \mathrm{~m})$, 19: slope meadows near Brzegi Górne $(850-900 \mathrm{~m}), 20$ : subalpine meadows on Dział $(100-1150 \mathrm{~m})$, subalpine meadows on Mała Rawka $(1250 \mathrm{~m}), 22$ : subalpine meadows on Wielka Rawka (1300 m), 23: subalpine meadows on Połonina Caryńska $(1250 \mathrm{~m}), 24$ : wet meadows and gravel bank near Ustrzyki Górne (700 m), 25: valley and slope meadows near Wołosate $(720-770 \mathrm{~m}), 26$ : subalpine meadows on Bukowe Berdo (1000-1300 m), 27: subalpine meadows on Tarnica $(1270 \mathrm{~m}), 28$ : subalpine meadows and clearings near Rozsypaniec $(1030-1120 \mathrm{~m}), 29$ : slope meadows near Stuposiany $(600 \mathrm{~m}), 30$ : meadows and roadside vegetation near Muczne $(700-740 \mathrm{~m}), 31$ : subalpine meadows and clearings of Grandysowa Czuba and Obnoga (940-1110 m), 32: meadows at San river (650 m), 33: meadows near Tarnawa $(700 \mathrm{~m}), 34$ : slope meadows near the former village Bukowiec $(750-900 \mathrm{~m})$, 35: slope meadows and clearings near the former village Beniowa $(740-780 \mathrm{~m}), 36$ : slope meadows and clearings near the former village Sianki (800-840 m). 


\section{RESULTS}

From 1996 to 2002, we found 35 species of Orthoptera in the Bieszczady Mountains (Table 1). Although the numbers of species occurring in the Bieszczady National Park and outside the park were comparable, Carpathian species occurred mainly or exclusively in the national park. We found four Orthoptera species that had not previously been reported for the Bieszczady Mountains: Chorthippus pullus, Omocestus rufipes, Isophya kraussii and Isophya pienensis. In the town of Ustrzyki Dolne, we incidentally found Labia minor (Linnaeus, 1758), a species of Dermaptera that has not been reported for the Bieszczady.

Table 1. Records of Orthoptera at 36 sites (340-1300 m altitude) in the Bieszczady Mountains, 1996-2002. The table contains the earliest date (day/month) when we found an adult, the range of altitude at which species were found, habitat (meadows in valleys and riverside vegetation at 340-730 m altitude, slope meadows at 400-900 m, clearings at 650-1100 m, subalpine meadows at 1000-1300 m; + when a species occurred, ++ when a species was common in a habitat) and sites of occurrence. Sites 16-28 and 32-36 were situated in the Bieszczady National Park (Fig. 1).

\begin{tabular}{|c|c|c|c|c|c|c|c|c|}
\hline & Species & 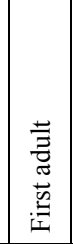 & $\begin{array}{l}\text { छ્ } \\
\text { 异 } \\
\text { 莺 }\end{array}$ & 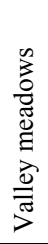 & 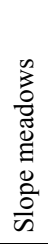 & 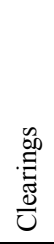 & 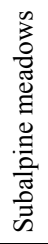 & Found at site \\
\hline 1 & 2 & 3 & 4 & 5 & 6 & 7 & 8 & 9 \\
\hline 1 & $\begin{array}{l}\text { Barbitistes constrictus Brunner v. Wattenwyl, } \\
1878\end{array}$ & $9 / 7$ & 1050 & & & + & & 14 \\
\hline 2 & Chorthippus albomarginatus (De Geer, 1773) & $28 / 7$ & $780-1300$ & & & + & + & $11,20,22,35$ \\
\hline 3 & Chorthippus apricarius (Linnaeus, 1758) & $27 / 6$ & $340-1150$ & + & ++ & + & + & $\begin{array}{l}1,2,4-6,8,9,12,17 \\
18,33-35\end{array}$ \\
\hline 4 & Chorthippus biguttulus (Linnaeus, 1758) & $13 / 7$ & $340-1300$ & + & ++ & + & ++ & $\begin{array}{l}1,2,5,8-12,17,18 \\
20-22,34,35\end{array}$ \\
\hline 5 & Chorthippus brunneus (Thunberg, 1815) & $5 / 7$ & $400-1300$ & & + & + & ++ & $\begin{array}{l}2,9,14,17,20-23,26, \\
34,35\end{array}$ \\
\hline 6 & Chorthippus dorsatus (Zetterstedt, 1821) & $4 / 8$ & $480-650$ & & + & & & 4,8 \\
\hline 7 & Chorthippus montanus (Charpentier, 1825) & $5 / 7$ & $340-1300$ & + & ++ & + & ++ & $\begin{array}{l}1,2,4,5,8-12,14,17 \\
20-22,33-35\end{array}$ \\
\hline 8 & Chorthippus parallelus (Zetterstedt, 1821) & $27 / 6$ & $340-1200$ & ++ & ++ & ++ & ++ & $\begin{array}{l}1-6,8,10-12,14,16- \\
20,24,25,30,33-36\end{array}$ \\
\hline 9 & Chorthippus pullus (Philippi, 1830) & $28 / 7$ & $700-760$ & + & & + & & 24,35 \\
\hline 10 & Chrysochraon dispar (Germar, [1834]) & $27 / 6$ & $340-1300$ & ++ & ++ & ++ & ++ & $\begin{array}{l}1-6,8-12,17-22,24 \\
25,33-35\end{array}$ \\
\hline 11 & Decticus verrucivorus (Linnaeus, 1758) & $30 / 6$ & $340-1300$ & ++ & ++ & + & + & $\begin{array}{l}1,3,5,8,9,18-22,25 \\
30,33-36\end{array}$ \\
\hline 12 & Euthystira brachyptera (Ocskay, 1826) & $6 / 6$ & $340-1250$ & ++ & ++ & ++ & ++ & $\begin{array}{l}1-14,16-21,24,25 \\
28-36\end{array}$ \\
\hline 13 & Gomphocerippus rufus (Linnaeus, 1758) & $6 / 8$ & $400-650$ & + & + & & & $2,3,9$ \\
\hline 14 & Gryllus campestris Linnaeus, 1758 & $13 / 6$ & 630 & & + & & & 15 \\
\hline 15 & Isophya camptoxypha (Fieber, 1853) & $10 / 7$ & 1230 & & & & + & 17 \\
\hline 16 & Isophya kraussii Brunner von Wattenwyl, 1878 & $1 / 7$ & $720-1150$ & & & + & + & $25,26,31$ \\
\hline 17 & Isophya pienensis Mařan, 1954 & $2 / 7$ & $600-1100$ & ++ & + & ++ & + & $18,26,29-31$ \\
\hline 18 & Isophya posthumoidalis Bazyluk, 1971 & $4 / 7$ & $700-730$ & + & & & & 30 \\
\hline 19 & Leptophyes albovittata (Kollar, 1833) & $27 / 6$ & 520 & + & & & & 6 \\
\hline 20 & Meconema thalassinum (De Geer, 1773) & $22 / 8$ & 500 & & & + & & 6 \\
\hline
\end{tabular}




\begin{tabular}{|c|c|c|c|c|c|c|c|c|}
\hline 1 & 2 & 3 & 4 & 5 & 6 & 7 & 8 & 9 \\
\hline 21 & Metrioptera bicolor (Philippi, 1830) & $30 / 6$ & $340-1250$ & + & + & + & + & $1,3,11,14,20,23$ \\
\hline 22 & Metrioptera brachyptera (Linnaeus, 1761) & $3 / 8$ & $750-1100$ & & + & & + & $12,19,25$ \\
\hline 23 & Metrioptera roeselii (Hagenbach, 1822) & $23 / 6$ & $340-1300$ & ++ & ++ & ++ & ++ & $\begin{array}{l}1,3-6,8-10,12-14 \\
16-22,24,25,29-36\end{array}$ \\
\hline 24 & Miramella ebneri carpathica Čejchan, 1958 & $1 / 7$ & $740-1300$ & + & + & + & + & $17,27,28,30,34,36$ \\
\hline 25 & Myrmeleotettix maculatus (Thunberg, 1815) & $28 / 7$ & 780 & & & + & & 35 \\
\hline 26 & $\begin{array}{l}\text { Omocestus haemorrhoidalis (Charpentier, } \\
1825 \text { ) }\end{array}$ & $1 / 7$ & $750-1300$ & & & + & + & $22,28,35$ \\
\hline 27 & Omocestus rufipes (Zetterstedt, 1821) & $30 / 8$ & 1250 & & & & + & 21 \\
\hline 28 & Omocestus viridulus (Linnaeus, 1758) & $26 / 5$ & $340-1270$ & ++ & ++ & ++ & ++ & $1-14,16-21,24-36$ \\
\hline 29 & Pholidoptera aptera slovaca Mařan, 1952 & $5 / 7$ & $1000-1120$ & & & & + & 10,13 , c.f. 28 (larvae) \\
\hline 30 & Pholidoptera griseoaptera (De Geer, 1773) & $30 / 6$ & $340-1200$ & ++ & ++ & + & + & $\begin{array}{l}1,3,5,6,8,9,11,15- \\
20,24,25,29-34\end{array}$ \\
\hline 31 & Stenobothrus lineatus (Panzer, 1796) & $21 / 7$ & $480-1300$ & & + & + & + & $\begin{array}{l}3-5,8,11,20-22,35 \\
36\end{array}$ \\
\hline 32 & Tetrix subulata (Linnaeus, 1758) & $19 / 6$ & $400-750$ & + & + & + & & $2,6,9,35$ \\
\hline 33 & Tetrix tenuicornis Sahlberg, 1893 & $4 / 6$ & $400-750$ & + & + & + & & $2,4-7,18,29$ \\
\hline 34 & Tetrix undulata (Sowerby, 1806) & $13 / 7$ & 800 & & + & & & 18 \\
\hline 35 & Tettigonia cantans (Füssli, 1775) & $1 / 7$ & $340-1200$ & ++ & ++ & ++ & + & $\begin{array}{l}1-6,8-11,15-20,24 \\
25,28,30,33-36\end{array}$ \\
\hline
\end{tabular}

We recorded four species of the genus Isophya. We found I. kraussii mostly on clearings and subalpine meadows of the eastern Bieszczady (northeastern slope of Bukowe Berdo, sites 26 and 31), but also on a valley meadow near Wołosate at $720 \mathrm{~m}$ (site 25). I. pienensis occurred in the same region but we did not find it together with I. kraussii. I. pienensis was widespread and abundant on meadows below $1000 \mathrm{~m}$. We also found this species along roads and in willow (Salix caprea) thickets of former meadows. We only found I. posthumoidalis near the village Muczne (site 30). The species lived at high population densities on roadsides overgrown with tall vascular plants (Petasites sp.) and grasses. We found I. camptoxypha only in the western part of the Bieszczady National Park. Whereas I. kraussii and especially $I$. pienensis already began to call at noon, I. posthumoidalis did not start calling before dusk. We heard but could not record calls of I. camptoxypha.

Most individuals of Chorthippus montanus, Chorthippus parallelus, Chrysochraon dispar, Euthystira brachyptera, and Metrioptera bicolor that occurred on subalpine meadows were long-winged, and those of Metrioptera roeselii were occasionally long-winged. We sometimes found long-winged individuals of Chorthippus parallelus, Euthystira brachyptera, and Metrioptera roeselii in clearings or meadows at lower altitudes $(600-1000 \mathrm{~m})$. We once found a Chorthippus pullus female with wings to the end of the abdomen in a forest clearing whereas individuals on a gravel bank had wings of normal size.

\section{DISCUSSION}

In the 1960s, Bazyluk (1971) reported four species of Isophya: I. brevipennis Brunner von Wattenwyl, 1878 (common), I. stysi Čejchan, 1958 (rare), I. camptoxypha (common), and I. posthumoidalis (localised in the western Bieszczady), whereas we found the four species $I$. kraussii (localised in the eastern Bieszczady), I. pienenis (common), I. camptoxypha (localised in the western Bieszczady National Park), and I. posthumoidalis (localised in the eastern Bieszczady). I. posthumoidalis, which was described by Bazyluk (1971) in the western Bieszczady, was recently also found in Slovakia (Kocarek \& Jeziorski 1999). Rather than a 
change in the species composition, different taxonomic interpretation may be partly responsible for the exchange of two species. However, species of the genus Isophya are difficult to identify by morphological characteristics only (Heller 1988). It is likely that taking the calls of males into account will result in the description of new species and the synonymisation of formerly separated species (Heller et al. 2004). Bazyluk (1971) already noticed that the morphology of $I$. camptoxypha was particularly variable and that some individuals were similar to those of Slovakian individuals of I. pienensis. Bazyluk (1971) described I. brevipennis, which is now considered as synonym of I. camptoxypha (Heller et al. 2004), as a species widely distributed in the higher Bieszczady (sites 10-36). However, Bazyluk (1971) wrote that individuals of $I$. brevipennis on Mały Jasło and Jasło (study site 12) differed from those of other sites by longer elytra and slightly shorter ovipositors, and wondered if they belonged to two subspecies. It is therefore possible that the species we recorded as I. kraussii, I. camptoxypha, and I. pienensis are the same species that Bazyluk (1971) identified as I. brevipennis and I. camptoxypha in the 1960s. Bazyluk (1971) found I. stysi only near our sampling site 28, where we did not find the species. We however heard an unknown species at site 30 with a bat detector, but as we could not find the individual, we are not able to rule out that the species still occurs.

In the 1960s, Bazyluk (1971) found six species (Chorthippus vagans, Conocephalus dorsalis, Oedipoda caerulescens, Stethophyma grossum, Tetrix bipunctata, Tettigonia viridissima) on sites that we did not visit during our study. We did not find these species but it is possible that they still exist in the Bieszczady Mountains. We could not find another four species that Bazyluk (1971) had recorded (Aiolopus thalassinus, Chorthippus mollis, Stenobothrus stigmaticus, Psophus stridulus). We assume that two of these species, Aiolopus thalassinus and Psophus stridulus, which also figure on the Polish red list (Liana 1992), may have disappeared from the subalpine meadows, perhaps as a result of changes in the vegetation structure. After cattle grazing stopped, the subalpine meadows developed into a dense Vaccinium-dominated habitat, which may not have left enough areas of short grass and bare soil for these species. However, Liana (2000) wrote that Aiolopus thalassinus was already rare in the 1960s and that these animals were probably dispersing individuals rather than residents. It is also possible that Stenobothrus stigmaticus disappeared, as short-grass meadows intensively grazed by sheep, which are necessary for this species, are now rare in the Bieszczady. It is unlikely that the common species Chorthippus mollis has disappeared from the region. The species develops relatively late in summer and our study time might have been too early for this species to be found.

Although subalpine meadows fell into disuse 60 years ago, they remained an important habitat for most Orthoptera species of the Bieszczady Mountains. The Carpathian species (Isophya spp., Miramella ebneri carpathica, Pholidoptera aptera slovaca) especially do not seem to have been significantly affected by the shift in land use. It is possible that many species persisted to this date as, since being abandoned, many meadows have been grazed by wild ungulates (red deer Cervus elaphus, roe deer Capreolus capreolus, European bison Bison bonasus). In winter, however, ungulates have to move from high altitudes of the national park to lower altitudes outside the park where deer are hunted. From an Orthoptera and general conservation perspective, it is desirable that hunting of deer in the surroundings of the national park is low to allow ungulate densities to remain relatively high.

\section{ACKNOWLEDGEMENTS}

We thank K.-G. Heller (Magdeburg, Germany) for identifying the Isophya and the Bieszczady National Park for issuing permissions to collect Orthoptera. 


\section{REFERENCES}

AUGUSTYN M. 2004. Anthropogenic changes in the environmental parameters of Bieszczady Mountains. Biosphere Conserv. 6: 43-53.

BAZYLUK W. 1971. Prostoskrzydłe (Orthoptera) Bieszczadów Zachodnich wraz z opisem Isophya posthumoidalis n. sp. Fragm. Faun. 17: 127-159. [with Russian and French summary].

Froehlich C. \& Holtzem E. 1987. Neue Methode zum Auffinden und Bestimmen von Heuschrecken (Saltatoria) im Freiland. Z. Angew. Zool. 74: 501-503.

HELLER K.-G. 1988. Bioakustik der europäischen Laubheuschrecken. Ökologie in Forschung und Anwendung 1: 1358.

Heller K.-G., Korsunovskaya O., Ragge D. R., Vedenina V., Willemse F., Zhantiev R. D. \& Frantsevich L. 1998. Check-list of European Orthoptera. Articulata Beiheft 7: 1-61.

Heller K.-G., OrCi K. M., Grein G. \& IngRisch S. 2004. The Isophya species of Central and Western Europe (Orthoptera: Tettigonoidea: Phaneropteridae). Tijdschr. Entomol. 147: 237-258.

HochKIRCH A. 1996. Die Bedeutung der Eiablage in Totholz für Habitatbindung und Ausbreitung bei Chrysochraon dispar (Germar, 1831). Articulata 11: 91-97.

KOCAREK P. \& JEZIORSKI P. 1999. First record of Isophya posthumoidalis (Orthoptera, Tettigoniidae, Phaneropterinae) from Slovakia. Biologia 54: 158.

LiANA A. 1992. Owady prostoskrzydłe Orthoptera [Orthopteroid insects]. In: GŁOWACIŃSKi Z. (ed.), Czerwona lista zwierząt ginących i zagrożonych w Polsce [Red list of threatened animals in Poland], pp. 85-91, Polish Academy of Sciences, Nature Protection Research Centre Kraków. [with English summary].

LiANA A. 2000. Prostoskrzydłe (Orthoptera), skorki (Dermaptera) i karaczany (Blattodea) Bieszczadów [Orthoptera, earwigs (Dermaptera) and cockroaches (Blattodea) in the Bieszczady Mountains]. Monografie Bieszczadzkie 7 : 173-189. [with English summary].

\section{STRESZCZENIE}

\section{[Nowe stwierdzenia Orthoptera w Bieszczadach (Południowo-Wschodnia Polska) ze specjalnym uwzględnieniem rodzaju Isophya]}

Użytkowanie łąk bieszczadzkich znacznie zmniejszyło się w ciagu ostatnich 60-ciu lat. Badania prowadzone na polanach i połoninach Bieszczad w latach 1996-2002 wykazały występowanie 35 gatunków Orthoptera. Cztery z nich wykazano z Bieszczad po raz pierwszy. Sa to: Isophya kraussii, I. pienenis, Chorthippus pullus oraz Omocestus rufipes. Nie stwierdzono natomiast trzech gatunków karpackich wykazanych we wcześniejszych badaniach. Autorzy przypuszczają, że gatunki te nie występują już w Bieszczadach z powodu znacznego ograniczenia wypasu bydła. Mimo to, uznają, iż skład gatunkowy karpackich prostoskrzydłych został zmieniony w niewielkim stopniu. 